\title{
POLITYKA PUBLICZNA W TRADYCJI ANGLOSASKIEJ I KONTYNENTALNEJ Z PERSPEKTYWY UKRAIŃSKIEJ
}

\section{Abstract \\ Public policy in Anglo-Saxon and continental tradition from Ukrainian perspective}

The purpose of this article is to present the development of the concept of public policy, which is based on British common law legal system, referring to the concept of politics as the activity of political parties or politicians, involved in competing for that power. Discussing the stages of shaping public policy separately from political science, the overview of the theories, models and main approaches (top-down, bottom-up) to the role of the state in the implementation of public policies in Anglo-Saxon tradition is introduced. The changes in the continental and the EU countries' tradition of public policy analysis are presented from Ukrainian perspective at the end of the article.

Keywords: politics and public policy, top-down and bottom-up theories, Anglo-Saxon and continental tradition of public policy, public policy in the EU, public policy in Ukraine

\section{Streszczenie}

Artykuł ma na celu przedstawienie rozwoju pojęcia polityki publicznej, które pochodzi z charakterystycznego dla brytyjskiej tradycji porządku prawnego, w odniesieniu do polityki jako działalności partii politycznych czy polityków konkurujących o władzę. Przeglądu etapów kształtowania polityki publicznej dokonano niezależnie od nauk politycznych, a teorie, modele, główne podejścia (odgórne i oddolne) oraz pola badawcze polityki publicznej w tradycji anglosaskiej pokazano w kontekście wyznaczania roli państwa w realizacji polityk publicznych. Zmiany, który zaszły w analizie polityk publicznych w tradycji kontynentalnej, przedstawiono z perspektywy krajów UE oraz Ukrainy.

Słowa kluczowe: polityka publiczna, polityki publiczne, odgórna i oddolna teoria, anglosaska i kontynentalna tradycja polityki publicznej, polityka publiczna w krajach UE, polityka publiczna na Ukrainie 


\section{Wprowadzenie}

Reakcją na zmiany społeczne zachodzące w ostatnich dziesięcioleciach pod wpływem takich trendów XXI wieku, jak globalizacja, wzrost roli klasy kreatywnej, zanikanie bariery między ludźmi a maszynami, wykorzystanie „zielonej” energetyki, są również procesy związane z przekształceniem zasad i narzędzi prowadzenia spraw publicznych. W ostatnim półwieczu wyjątkowo duże znaczenie ma polityka publiczna, rozumiana jako proces podejmowania systemowych działań państwa i społeczeństwa wokół nowych i narastających problemów publicznych. Uwzględniając zasady nowego zarządzania publicznego i zarządzania partycypacyjnego (tzw. koncepcji współzarządzania), polityki publiczne odnoszą się do pojęcia władzy w szerszym jej znaczeniu, obejmując obszerny zakres działań aktorów oraz interesariuszy uczestniczących w zarządzaniu każdym konkretnym typem polityki publicznej (np. polityki społecznej, polityki rozwoju itp.). W zależności od kryteriów badawczych polityki publiczne cechują się zróżnicowaniem kulturowym, finansowym, polityczno-systemowym lub instytucjonalnym na poziomie państw [Adolino, Blake, 2001].

Jak wskazuje Ryszard Szarfenberg [2013: 25], proces wyjścia poza wąsko prawnicze myślenie o administracji państwowej w kierunku polityki publicznej w Polsce rozpoczął się po jej wejściu do Unii Europejskiej. W ostatnich latach badacze tacy jak Jerzy Hausner, Andrzej Zybała, Stanisław Mazur, Grażyna Prawelska-Skrzypek oraz R. Szarfenberg podjęli próbę zestawienia teoretycznego dorobku anglosaskiej tradycji analizy polityki publicznej z polskimi realiami życia publicznego. Podobne wyzwanie stoi przed ukraińskimi teoretykami i praktykami reformy samorządowej, rozpoczętej w 2014 roku i ukierunkowanej na całkowitą zmianę odziedziczonego po Związku Radzieckim odgórnego systemu zarządzania publicznego.

Celem niniejszego artykułu jest przedstawienie ujęć teoretycznych polityki publicznej w tradycji anglosaskiej i kontynentalnej oraz ich odniesienie do wyboru modelu polityki publicznej na Ukrainie w związku z trwającą reformą samorządową. Przy opisie polityki publicznej z perspektywy ukraińskiej w nawiązaniu do tradycji anglosaskiej oraz kontynentalnej szczególnie ważna dla analizy zmian, które zaszły w toku tworzenia się nauki o polityce publicznej, jest metoda historyczno-porównawcza. Nie mniej istotna jest także wstępna analiza językowej różnicy znaczenia pojęć, która w jakimś stopniu odzwierciedla semantyczno-kulturowe zasady kształtowania się odgórnych czy oddolnych modeli polityki publicznej.

\section{Polityka publiczna w tradycji anglosaskiej}

Samo pojęcie polityki publicznej pochodzi z charakterystycznego dla krajów anglosaskich porządku prawnego, a konkretnie z tzw. prawa precedensowego (common law), które opierało się na tradycji zwyczajowej oraz zasadzie precedensu. 
Przed XVIII wiekiem pojęcie polityki publicznej rzadko pojawiało się w sprawach sądowych. Jednym z najstarszych przykładów jest sprawa Johna Dyersa z 1413 roku, w której powołano się na zasadę szkodliwego działania dla wspólnoty lub przeciwko dobru wspólnoty [Ghodoosi, 2016: 5-6]. Ten przypadek pokazuje tradycyjne znaczenie polityki publicznej, mającej na celu ochronę wspólnoty przed naruszeniem jej wartości i obyczajów. W 1750 roku lord Hardwicke jako jeden z pierwszych użył określenia „polityka publiczna” w znaczeniu państwowo-politycznym i w taki sposób, aby prawa suwerena, jako podmiotu niezależnej władzy, zyskały znaczącą wagę w sądach. Uwzględniając powyższy aspekt pojęciowy, Farshad Ghodoosi określa znaczenie definicji zaproponowanej przez lorda Hardwickego jako przekształcenie koncepcji działań tylko przeciwko społeczności w postępowanie przeciwko res publica, tj. sprawom publicznym, co mogłoby oznaczać początek nowoczesnego podejścia do poziomów polityki publicznej [Ghodoosi, 2016: 5-6].

Polityzacja polityki publicznej negatywnie wpłynęła na rozwój prawa precedensowego w XIX wieku oraz spowodowała wyłonienie się dwóch nurtów rozumienia pojęcia polityki publicznej w tradycji anglosaskiej. Prezentując pierwsze podejście, wedle którego o odpowiedniości polityki publicznej powinien decydować organ prawodawczy, brytyjski sędzia James Burrough w 1824 roku nazwał ten typ polityki „bardzo niesfornym koniem”, ponieważ kiedy jeździ się na nim okrakiem, nigdy nie wiadomo, dokąd on zaprowadzi [Murphy, 1981: 593; Ghodoosi, 2016: 6]. Drugi nurt głosił, że sądy mogą decydować na korzyść interesów państwa wyłącznie w sytuacji realizacji polityki publicznej. Różnica między tymi dwoma nurtami polegała przede wszystkim na tym, że pierwszy zakładał bardziej pasywną rolę sędziów w ocenie polityki publicznej, drugi zaś zachęcał sądy do przyjmowania aktywnej postawy w podejmowaniu decyzji w interesach państwa.

Na początku XX wieku wśród angielskich sędziów wyraźnie dominowała tendencja, by powstrzymać poszerzanie się praw w zakresie polityki publicznej, mówiło się także o „wyjaśnieniu, ale nie rozszerzeniu” tej dziedziny prawa [Murphy, 1981: 592-593]. W praktyce takie opinie nie zahamowały rosnącego wpływu polityki publicznej na różne dziedziny życia społecznego, jednak ewidentnie wskazały na istotność oceny prawnej i ustalenia procedury zawierania kontraktów uprzednio umówionych między interesariuszami konkretnych polityk.

Jeszcze jednym ważnym uzupełnieniem w sferze polityki publicznej była idea społeczeństwa obywatelskiego, której początek dał Arystoteles, a którą w XIX wieku na grunt tradycji amerykańskiej przeniósł francuski myśliciel Alexis de Tocqueville. W swoim fundamentalnym dziele $O$ demokracji w Ameryce, zawierającym analizę społeczeństwa demokratycznego, de Tocqueville zaproponował trójdzielny model: państwo - społeczeństwo polityczne - społeczeństwo obywatelskie, w którym społeczeństwo obywatelskie stanowi dziedzinę aktywności obywateli, ich zdolności do samoorganizacji w realizacji własnych interesów [Arczewska, 2017: 147]. Idea obywatelskości rozwinęła się w XVIII wieku na podstawie prawa osobistej wolności, prawa własności oraz prawa do ochrony przed nadużyciem władzy państwowej. Prawa polityczne zaczęto wprowadzać w XIX wieku przez proces wyborczy i powszechne prawo wyborcze. Społeczny wymiar 
obywatelskości, czyli prawo do akceptowanego poziomu społecznego wsparcia przez rząd, zaczął być realizowany po II wojnie światowej przez edukację, opiekę zdrowotną, mieszkalnictwo i opiekę społeczną w następstwie utworzenia państwa opiekuńczego [Wallace, 1993: 6].

Analiza polityki publicznej jako odrębnej dziedziny wiedzy o zarządzaniu wywodzi się ze Stanów Zjednoczonych. Na początku lat trzydziestych XX wieku wprowadzony w Stanach Zjednoczonych przez prezydenta Franklina Roosevelta program reform, tzw. nowy ład, miał na celu przezwyciężenie kryzysu przez wzrost regulacji państwowej życia ekonomicznego i społecznego. Jednak po II wojnie światowej demokratyzacja życia publicznego spowodowała nowe oczekiwania wobec działalności władz państwowych, m.in. wynikające z potrzeby szerszego uzgadniania jej ze społeczeństwem.

\section{Teorie, modele i pola badawcze polityki publicznej}

Za twórcę nauk o polityce publicznej uważany jest amerykański politolog Harold Lasswell, który w 1951 roku napisał esej Orientacje polityki. Lasswell próbował tu sformalizować zasady kształtowania się polityki publicznej, odrębne od nauki o polityce (politics), oraz relacje między naukami społecznymi.

Badacze drugiej generacji (T. Lowi, J.L. Pressman, A. Wildavsky, J. Anderson $\mathrm{i}$ in.) w latach siedemdziesiątych i osiemdziesiątych XX wieku podjęli alternatywne próby analizy polityki publicznej, skupiając się na rozwoju teorii polityki publicznej jako nowej dziedziny wiedzy. Rozwijając teorię Harolda Lasswella, James Anderson zaproponował koncepcję stadiów heurystycznych polityki publicznej, która w jego wersji składa się z pięciu faz. Poza Andersonem naśladowcami koncepcji stadiów heurystycznych było wielu badaczy, w tym m.in. Charles Jones i Randall Ripley. Schemat 1 przedstawia model, w którym każdemu z pięciu etapów kształtowania się polityki publicznej odpowiada makro- lub mikropoziom uczestnictwa interesariuszy. W fazie podejmowania decyzji wyłącznie organy władzy publicznej decydują o przyszłych działaniach z zakresu konkretnej polityki publicznej.

Oprócz koncepcji Andersona w literaturze anglosaskiej jednym z często przywoływanych ujęć jest to zaproponowane przez Theodora Lowiego, który uważał, że polityka publiczna determinuje działania polityczne (politics), a nie odwrotnie [Szarfenberg, 2016: 48-49]. Zestawił on dwa kryteria powiązane z małym lub dużym typem przymusu pozostającym $w$ dyspozycji rządu $\mathrm{z}$ dwoma sposobami oddziaływania (bezpośrednim lub pośrednim) jednostek i zaproponował cztery typy polityk publicznych:

1) dystrybucyjną - mały przymus i bezpośrednie oddziaływanie (wysoki poziom zaspokojenia zindywidualizowanych potrzeb, a także udostępnienie obywatelom kosztów na towary i usługi), 


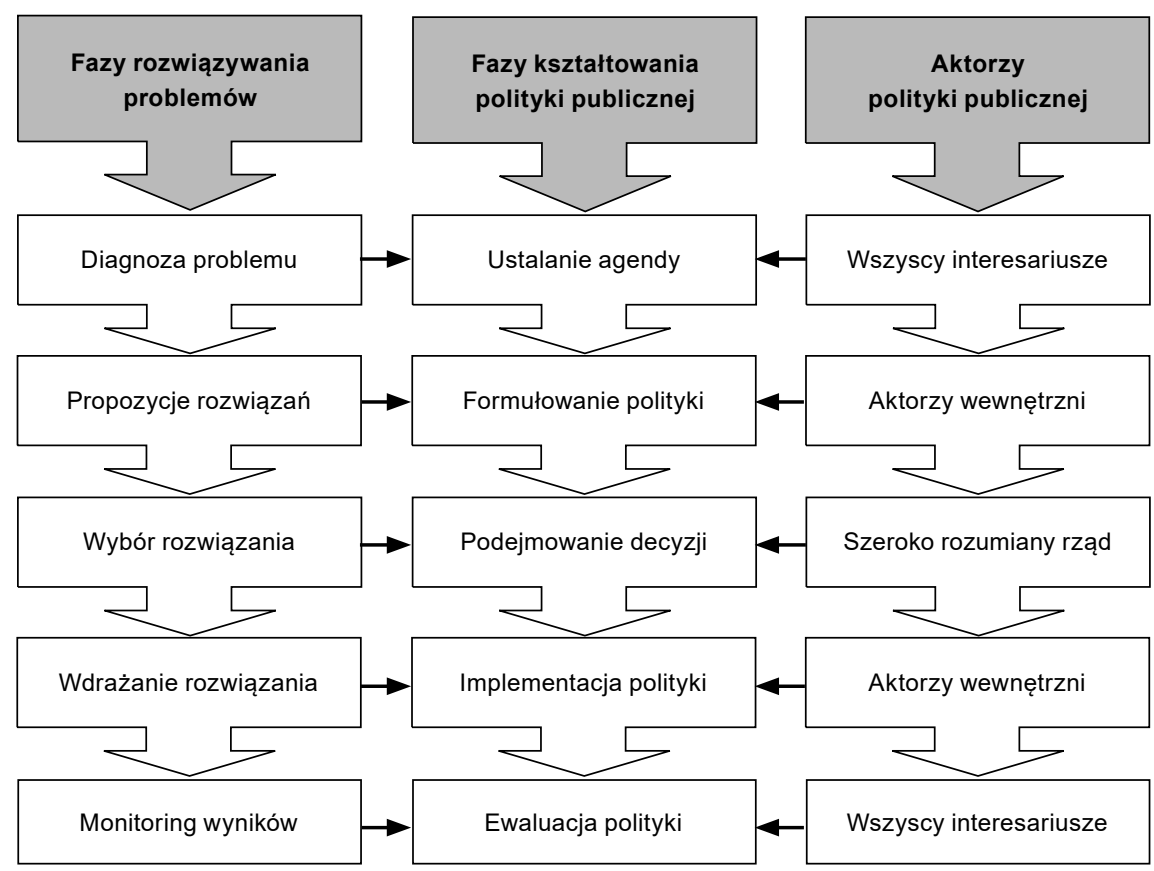

Schemat 1. Model stadialny kształtowania polityki publicznej w rozwiązywaniu problemów Źródło: opracowanie własne na podstawie Howlett, 2011: 19; Szarfenberg, 2016: 52.

2) regulacyjną - duży przymus i bezpośrednie oddziaływanie (określenie możliwości zachowań za pomocą mandatu, grzywny lub sankcji, np. ograniczenie prędkości),

3) konsty tutywną - mały przymus i pośrednie oddziaływanie (regulacja prawna lub podporządkowanie jednostkom władzy, w niektórych wypadkach dotyczącej również polityki fiskalnej),

4) redystrybucyjną - duży przymus i pośrednie oddziaływanie (celowe oddziaływanie za pomocą instrumentów prawnych lub podatkowych, które wpływa na podział dochodu lub dóbr, np. progresywne opodatkowanie) [Lowi, 1972].

Krytyka podziału polityk publicznych na cztery typy pociągnęła za sobą nowe sposoby ich definiowania [Mazur, 2015: 19]. Na tym etapie pozytywistyczne podejście, które odwołuje się do zasad obiektywności i badań ilościowych, weszło w konflikt najpierw z konstruktywistyczną postawą badaczy, którzy byli przekonani o pierwszeństwie subiektywizmu, konwencjonalnego sposobu kształtowania się wiedzy naukowej i użyteczności metod jakościowych, a potem - w spór pomiędzy postawą krytyczną oraz postmodernistyczną. Na tle narastającej polemiki wokół pytań dotyczących efektywności administracji publicznej rozpoczęła się debata poświęcona teorii i metodom analizy polityk publicznych oraz modelom 
ich implementacji. Podejście do zarządzania z pozycji polityki publicznej ujmuje każdą fazę projektowania i wdrażania działań administracji jako element ogólnego modelu implementacji polityk, a także zwraca uwagę na rozszerzenie się możliwości udziału społeczeństwa obywatelskiego w tym procesie. Analiza polityki publicznej, która obejmuje zakres od definicji problemu do wyboru i zatwierdzenia rozwiązania, jest rozpatrywana przez złożoną sieć procesów politycznych i administracyjnych, której rezultatem są decyzje polityczne i zarządzające. Tą drogą w ramach modelu stadialnego (heurystycznego) wyłania się tzw. cykl polityk publicznych ( policy cycle).

Cykl polityk publicznych - począwszy od dostrzeżenia problemów publicznych i prywatnych, określenia problemu zgodnie z modelem implementacji, podejmowania decyzji o konkretnych działaniach, ich realizacji i kontroli - odzwierciedla wpływ polityki publicznej na zarządzanie administracyjne. Przy prowadzeniu polityki publicznej, z istoty ukierunkowanej praktycznie, w każdej z pięciu faz ważne jest postawienie odpowiednich zadań i pytań, które w końcu pozwolą przeprowadzić dokładną ewaluację realizowanych działań z zakresu polityki publicznej. Polityczną składową procesu decyzyjnego jest interakcja podmiotów (aktorów) polityki publicznej, w wyniku której podejmowana jest konkretna decyzja.

W latach siedemdziesiątych i osiemdziesiątych XX wieku rozpoczęła się naukowa dyskusja o badaniach nad implementacją polityki publicznej, a także ukształtowały się dwa główne podejścia do roli państwa w implementacji polityk publicznych: odgórne, osadzone w hierarchii polityk zdefiniowanych centralnie, oraz oddolne - w którym wdrożenie polega na strategii codziennego rozwiązywania problemów na najniższym poziomie, np. na poziomie administracji pierwszego kontaktu (street-level bureaucracy). Duża ilość danych empirycznych, które dowodzą relatywności każdej z dwóch teorii, doprowadziła do ukształtowania się trzeciego, hybrydowego podejścia do implementacji polityk publicznych [Pülzl, Treib, 2007: s. 90].

Odgórna i oddolna koncepcja ukazują kontrastujące modele procesu implementacji polityki. Celem analizy przedstawicieli odgórnej szkoły (Van Meter i Van Horn, Nakamura i Smallwood, Mazmanian i Sabatier) jest stworzenie ogólnej teorii implementacji polityki publicznej. Uczonych nurtu oddolnego zaś (Lipsky, Ingram, Elmore, Hjern i Hull) łączy empiryczne postrzeganie i wyjaśnianie interakcji oraz strategii rozwiązywania problemów podmiotów zaangażowanych w realizację polityki. Model teorii odgórnej przewiduje, że cykl polityk można podzielić na kilka wyraźnie ukształtowanych faz. W taki sposób odgórna analiza nie dotyczy całego procesu, a jedynie tego, co następuje po uchwaleniu ustawy lub rozporządzenia. Natomiast podejścia oddolne wychodzi z założenia, że tworzenie się polityki trwa przez cały cykl, włączając implementację polityki, której nie można oddzielić od procesu jej formułowania. Powyższe stwierdzenie ilustruje de facto alternatywny wobec stadiów heurystycznych sposób rozumienia procesu polityki publicznej - formułowanie polityki nie jest jednym z etapów, lecz dokonuje się na każdym etapie procesu polityki publicznej.

Pod koniec lat osiemdziesiątych XX wieku w analizie polityk dostrzega się myślenie postpozytywistyczne, które akcentuje elementy dyskursywne, takie 
jak wartości, idee, język. W latach dziewięćdziesiątych z kolei polityka publiczna ukształtowała się jako odrębny obszar badań, często konkurujący z zarządzaniem publicznym.

\section{Terminologiczne i instytucjonalne podstawy analizy polityki publicznej w tradycji kontynentalnej}

W tradycji kontynentalnej od początku kształtowania się polityki publicznej jako dziedziny wiedzy pojawiają się problemy już na poziomie definiowania samego terminu. W językach niemieckim, francuskim, polskim czy ukraińskim pojęcie „polityka” oznacza zarówno działalność władzy w państwie, jak i działalność partii politycznych czy polityków konkurujących o władzę [Szarfenberg, 2016], w języku angielskim zaś te dwa znaczenia mają dwa odrębne terminy - policy i politics. Policy oznacza strategie działań, programy lub własne działania konkretnych podmiotów, grup lub rządów. W tym znaczeniu mówi się o polityce edukacyjnej, polityce zdrowotnej czy o polityce zewnętrznej konkretnego rządu. Politics oznacza wszystko, co dotyczy debat publicznych, zmagań w celu uzyskania dostępu do władzy, a więc sfery walki i konkurencji o władzę [Reno, 2011].

W języku polskim pojęcie ,polityka” również jest złożonym terminem, który zdaniem Jerzego Hausnera wyznacza cztery płaszczyzny znaczeniowe:

- dyskursywną - podsystem (obok gospodarki i kultury) życia społecznego, którego atrybutem jest władza,

- strukturalną - system polityczny jako całość organizacji politycznych, wśród których najważniejszym jest państwo,

- behawioralną - celowe działanie podmiotów politycznych,

- funkcjonalno-techniczną - określoną dziedzinę działania władzy publicznej, np. polityka gospodarcza lub polityka oświatowa [Hausner, 2007].

Tak znacząca rozbieżność terminologiczna wskazuje na potrzebę odróżniania tradycji kontynentalnej od anglosaskiej.

Pierwszy etap badań naukowych w tradycji kontynentalnej, dotyczących kwestii implementacji polityk publicznych z perspektywy integracji europejskiej, był związany z przedstawicielami szkoły odgórnej, którzy opisywali przede wszystkim przykłady niepowodzeń we wdrażaniu sektorowych polityk publicznych na poziomie związku państw europejskich [Treib, 2006; 2014: 7-8). Krajowa polityka publiczna była wtedy przedstawiana raczej jako apolityczny proces, którego skuteczność zależała głównie od sformułowana zrozumiałych do wykonania przepisów, sprawnego funkcjonowania systemu zarządzania administracji publicznej i efektywnego systemu prawnego.

Drugi etap badań nad wspólną tradycją europejską implementacji polityk publicznych (policy tradition) rozpoczął się pod koniec lat dziewięćdziesiątych XX wieku. Dla ustalenia linii reform szczególne znaczenie miały argumenty oparte na stopniu „dopasowania” politycznych i administracyjnych procedur 
oraz odwoływanie się do historycznych i instytucjonalnych tradycji zarządzania [Treib, 2014: 8-9]. Niektóre rządy państw członkowskich próbowały wdrożyć własne modele polityki na poziomie europejskim, co wiązało się z dłuższą trwałością, ale i wysokim ryzykiem całkowitego niepowodzenia. Przedstawiciele kontynentalnego wariantu nauki o polityce publicznej zaproponowali dwie znaczące innowacje:

- nową metodologię przygotowania strategii, która wychodzi z międzynarodowych, a nie państwowych zasad, i wywodzi się z podejścia komparatywnego,

- rozszerzanie pola badawczego polityki publicznej przez jej otwarcie się na teorie polityki (political sciencies) i metodę porównawczą (comparative method).

Na drugim etapie najistotniejsze rezultaty badań i wdrażania wspólnych polityk krajów Unii Europejskiej nawiązywały do europejskiej polityki środowiskowej.

Trzeci etap charakteryzuje różnorodność podejść teoretycznych i metodologicznych związanych z badaniami jakościowymi skuteczności wdrażania europejskich dyrektyw na poziomie polityki wewnętrznej państw. Kolejnym ważnym aspektem jest wzrost badań ilościowych. Jak twierdzi Oliver Treib [2006: 11]:

[...] to wyjaśnia nam interesujący paradoks: podczas gdy studia jakościowe w trzeciej fali badań coraz częściej uwzględniają polityczny charakter wprowadzenia, wyniki badań ilościowych - odwrotnie - wskazują na argumenty pionierów badań unijnych, podkreślając ważne znaczenie efektywnej i dobrze skoordynowanej administracji1.

Na tle prowadzonych badań dużą reformę wprowadzała Unia Europejska - po podpisaniu 13 grudnia 2007 roku i od czasu wejścia w życie traktatu lizbońskiego, tj. 1 grudnia 2009 roku. W ramach dorobku Unii Europejskiej analizuje się dwa modele demokracji: większościowy i stowarzyszeniowy. Jeśli pierwszy opiera się na otwartej rywalizacji sił politycznych z szerokim zakresem uprawnień do realizowania swojego programu politycznego po tworzeniu własnego rządu, to model stowarzyszeniowy opiera się na zasadach inkluzywności, kompromisów i współrządzenia. Aczkolwiek zdaniem Andreasa Warntjena współczesna praktyka podejmowania decyzji w Radzie Europejskiej bardziej odpowiada modelowi konsensusu, a zmiany przedstawione w traktacie lizbońskim prawdopodobnie nie będą wprowadzone do praktyki Unii Europejskiej [Warntjen, 2016].

W krajach Unii Europejskiej każdy typ sektorowej, horyzontalnej, regulacyjnej, administracyjnej polityki publicznej jest używany do określenia polityki na poziomie państwa, która jest wynikiem wspólnych działań krajowych i ponadnarodowych organów zarządzających oraz interakcji z podmiotami niepaństwowymi. Zasady polityki publicznej w krajach Unii Europejskiej są uwzględnione w przepisach organizacji administracji publicznej i podane w Białej Księdze. Zgodnie z przepisami i rekomendacjami Unii Europejskiej ewaluacja oraz badanie

1 Tłumaczenie własne. 
rezultatów wdrażania polityk publicznych mają teraz coraz większe znaczenie dla administracji publicznej [Kozaczka, 2016: 324].

Oficjalnie polska tradycja polityki publicznej jako odrębnej dyscypliny wiedzy zaczęła się od 2011 roku, kiedy Rozporządzeniem Ministra Nauki i Szkolnictwa Wyższego z 8 sierpnia 2011 roku nauki o polityce publicznej wpisano do dyscyplin naukowych [Kozaczka, 2016: 323]. W tak krótkim czasie, zdaniem A. Zybały [2015: 28], trudno mówić w Polsce o wypracowaniu szerszej wiedzy w zakresie teorii, które mogą wyjaśnić procesy formowania polityk, czyli modeli przebiegu działań publicznych. Odwołując się do idei Leslie Pala [2011], który pisze o braku tradycji w zakresie analizy polityki publicznej w Europie Centralnej i Wschodniej, A. Zybała twierdzi, że takie same problemy, związane z poszukiwaniem własnej tożsamości w tej dziedzinie wiedzy, dostrzegają również państwa na podobnym czy nieco wyższym poziomie rozwoju. Jednocześnie, przy analizie anglosaskiej tradycji polityki publicznej dochodzi do wniosku, że przydatność tej teorii do analizy polityki publicznej w Polsce jest bardzo mała ze względu na zakorzenienie polskiej tradycji w linearnym modelu polityki. Linearność w odrębnych politykach oznacza dominującą rolę instytucji państwa (administracji publicznej i klasy politycznej), skłonność do jednostronnego działania, zachowanie instrumentów kontroli, niski udział aktorów i słabe znaczenie opinii ekspertów w procesach decyzyjnych oraz brak otwartych przetargów [Zybała, 2015: 32].

\section{Dylemat wyboru między polityką publiczną a zarządzaniem państwowym: doświadczenia ukraińskie}

W instytucjonalnym dziedzictwie państw byłego Związku Radzieckiego, z którym Ukraina nadal stara się rozliczyć, pojęcie polityki publicznej nadal jest podporządkowane polityce państwowej, pojmowanej jako wybrany przez organy władzy państwowej przebieg działań lub powstrzymania się od nich w celu rozwiązania konkretnego problemu. Na to nałożyło się tłumaczenie na język ukraiński w ostatnich latach XX wieku anglojęzycznego pojęcia public policy jako „polityka państwowa” (ukr. державна політика). Niektórzy badacze ukraińscy próbowali wyjaśnić wspólne i odmienne cechy polityki państwowej i publicznej, chociaż tak naprawdę chodzi tu nie tyle o różnicę pojęć, ile o różne modele systemu państwa, przejście od odgórnego systemu zarządzania publicznego do zarządzania partycypacyjnego.

Zamęt terminologiczny, który nadal panuje na Ukrainie w tym zakresie, związany jest także z częstym utożsamianiem takich pojęć, jak „zarządzanie państwowe”, „administracja publiczna” czy „zarządzanie publiczne”. Od 1997 roku zarządzanie państwowe, zgodnie z Dekretem Gabinetu Ministrów Ukrainy z 29 listopada 1997 roku, uznano za odrębną dyscyplinę wiedzy w zakresie kształtowania zasad i mechanizmów wpływu władz państwowych na życie społeczne przez regulację, organizację i koordynację, a takie dziedziny, jak zarządzanie publiczne i administrowanie - za subdyscypliny zarządzania państwowego. Na tym 
etapie rozpoczęła się dyskusja o zmianie pojęć, przymiotników i metod $-\mathrm{z}$ „zarządzania państwowego" na ,zarządzanie publiczne”. W słowniku encyklopedycznym z 2010 roku pojęcie polityki publicznej porównano z władzą publiczną jako połączeniem zarządzania państwowego i samorządności publicznej, realizowanej nie tylko w interesie państwa, ale i w celu zaspokojenia potrzeb społeczeństwa jego klas, grup czy indywidualnych podmiotów [Goshovska, 2010]. Rok późnej, czyli w 2011 roku, w ośmiotomowym wydaniu encyklopedii zarządzania państwowego politykę publiczną określa się jako:

- działalność organów administracji publicznej ukierunkowaną na rozwiązywanie problemów społecznych,

- stosowaną dyscyplinę z nauk społecznych i edukacyjnych, która zajmuje się badaniem działalności organów administracji publicznej i jest ukierunkowana na rozwiązywanie problemów społecznych [Zagors'kyj, Bunyk, 2011].

Od 2014 roku na Ukrainie trwa proces reformowania systemu administracyjnego, politycznego oraz sądownictwa w kierunku decentralizacji, partycypacji i subsydiarności. Teoretycy próbują wyjaśnić i dostosować do ukraińskich realiów współczesne modele nowego zarządzania publicznego, współzarządzania czy zarządzania sieciowego, aczkolwiek w ich propozycjach nadal widoczny jest silny wpływ odgórnych teorii polityk publicznych i etatystycznych modeli zarządzania. Schemat 2 prezentuje pojęcie polityki jako władzy publicznej, przy czym odzwierciedla również odgórną wizję kształtowania się polityk publicznych.

Decentralizacja władzy, która wywodzi się z idei samorządności terytorialnej, jest niezbędnym $\mathrm{i}$ jednym $\mathrm{z}$ najważniejszych założeń przy zmianie polityki państwowej na politykę publiczną. Główne założenia reformy samorządowej zostały przyjęte przez rząd Ukrainy w kwietniu 2014 roku, a w lipcu parlament Ukrainy (Rada Najwyższa) rozpoczął debatę nad projektem zmian w konstytucji związanych z decentralizacją władzy. Reforma samorządowa przewiduje oczyszczenie z dziedzictwa postradzieckiego i przekształcenie całego systemu zarządzania publicznego z różnymi podmiotami polityk publicznych o różnych kompetencjach. Jednym $z$ istotnych kroków na drodze do wprowadzenia reformy było uchwalenie 5 lutego 2015 roku Ustawy o dobrowolnym zjednoczeniu terytorialnym hromad, stworzono też podstawę materialną i finansową ich działalności. Hromady to nowe dla ukraińskiego ustawodawstwa jednostki samorządu terytorialnego. 25 października 2015 roku dla 159 nowo utworzonych hromad zostali wybrani ich szefowie i radni. Już dziś reformę decentralizacji można uznać za jedną z najbardziej udanych na Ukrainie. Po wyborach 29 kwietnia 2018 roku w 40 nowo utworzonych hromadach na Ukrainie będzie już 705 zjednoczonych terytorialnych hromad z 1188 proponowanych przez rząd Ukrainy. Cały czas jednak jest to wstępny etap reform samorządowych, które również potrzebują odpowiedniego modelu kształtowania i wdrażania polityk publicznych. 


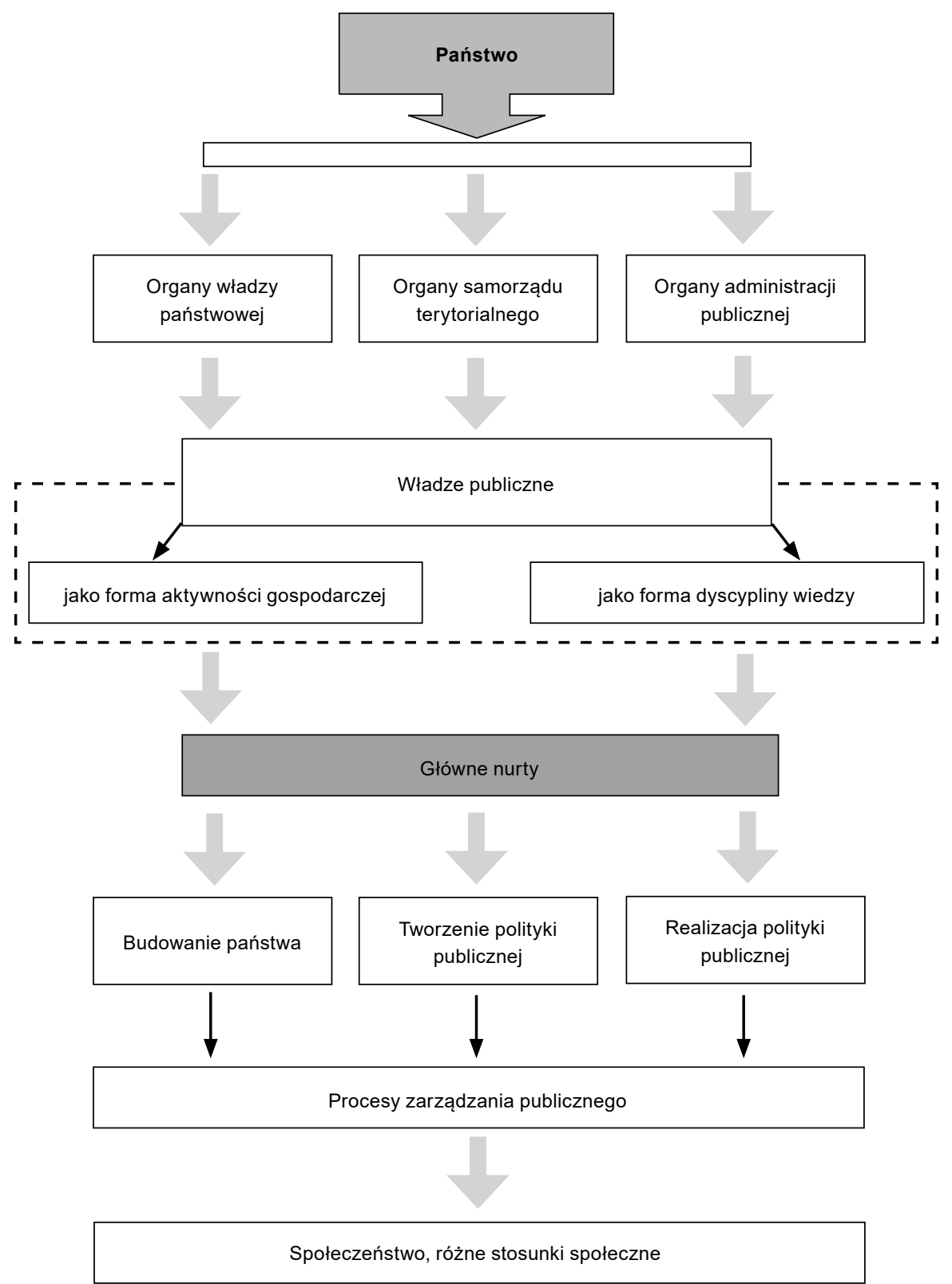

Schemat 2. Model zarządzania publicznego w podejściu systemowym

Źródło: opracowanie własne na podstawie Bakumenko i in., 2016: 16. 


\section{Wnioski}

Od wejścia Polski do Unii Europejskiej w dokumentach rządowych, publikacjach eksperckich oraz naukowych coraz częściej pojawia się pojęcie „polityka publiczna”. Wprowadzenie pojęcia polityki publicznej do polskiej tradycji zarządzania oznaczało odejście od dominującego wpływu państwa na podejmowanie działań publicznych. Duże miasta, regiony i województwa prowadzą sektorowe polityki, a także polityki rozwoju o dość autonomicznym charakterze, chociaż uprawianie „realnej” polityki publicznej w Polsce wciąż jest odgórne. Najważniejsze instrumenty kontroli są skoncentrowane w narzędziach prawnych. Ich nieefektywność powoduje wysokie koszty działań publicznych, które mogłyby być realizowane przez podmioty sektora publicznego lub prywatnego na lepszych warunkach [Zybała, 2015: 33].

Z ukraińskiego punktu widzenia teoretyczne refleksje nad anglosaską i kontynentalną tradycją polityki publicznej są cennym materiałem poglądowym, aczkolwiek praktyka analizy oraz implementacji polityk publicznych zależy głównie od gotowości społeczeństwa do pozytywnych zmian. Ogólny kryzys zasad polityki międzynarodowej, potrzeba zachowania bezpieczeństwa na świecie, a szczególnie na Ukrainie, utrudnia proces szybkiego i efektywnego wdrażania demokratycznych reform. Wychodząc z takich założeń, do zasadniczych problemów towarzyszących wprowadzaniu praktyki polityki publicznej, które charakteryzują współczesną ukraińską rzeczywistość, należy zaliczyć:

- brak tradycji w zakresie analizy polityki publicznej i poszukiwanie własnej tożsamości instytucjonalnej przez modele, pojęcia, formy prawne zarządzania publicznego i implementacji polityk publicznych,

- dylemat wyboru między odgórnym i oddolnym modelem zarządzania publicznego i wdrażania polityk publicznych,

- binarne przewartościowanie życia publicznego w warunkach tzw. wojny hybrydowej, która trwa od czterech lat we wschodniej części Ukrainy, może wzmacniać autorytaryzm albo sprzyjać na poziomie lokalnym uświadomieniu konieczności szybkich reform, w tym reformy samorządowej, w tej części Ukrainy, która jest kontrolowana przez władze ukraińskie.

\section{Bibliografia}

Adolino J.R., Blake Ch.H. (2001), Comparing Public Policies: Issues and Choices in Six Industrialized Countries, CQPress, Washington.

Arczewska M. (2017), Polityka obywatelska (polityka publiczna wobec spoleczeństwa obywatelskiego) [w:] J. Kwaśniewski (red.), Nauki o polityce publicznej. Studia i materiały, t. 1, Instytut Profilaktyki Społecznej i Resocjalizacji Uniwersytetu Warszawskiego, Warszawa. 
Bakumenko V., Bondar I., Hornyk V., Shpachuk V. (2016), Osoblyvosti publichnoho upravlinnya ta administruvannya, KNUKiM, Kyiv.

Bunyk M. (2015), Osnovy analizu derzavno i polityky, L'viv Regional Institute of Public Administration under the President of Ukraine, L'viv.

Ghodoosi F. (2016), International Dispute Resolution and the Public Policy Exception, Routledge, London.

Goshovska V. (2010), Publichna polityka [w:] Yu. Kovbasyuk, V. Troshchinsky, Yu. Surmin (eds.), Encyclopaedic Dictionary of Public Administration, National Academy of Public Administration under the President of Ukraine, Kyiv.

Hausner J. (2007), Polityka a polityka publiczna, ,Zarządzanie Publiczne” (Uniwersytet Ekonomiczny w Krakowie), 1, 43-60.

Howlett M. (2011), Designing Public Policies, Routledge, New York.

Kozaczka D. (2016), Polityki publiczne jako proces, „Zoon Politikon”, 7, 323-341.

Lowi Th.J. (1972), Four Systems of Policy, Politics, and Choice, „Public Administration Review”, 32(4).

Mazur S. (2015), Założenia teoretyczne i metodologiczne nauk o polityce publicznej, „Wrocławskie Studia Politologiczne", 18.

Murphy K. (1981), The Traditional View of Public Policy and Ordre Public in Private International Law, „The Georgia Journal of International and Comparative Law”, 11, 3.

Pal L.A. (2010), Beyond Policy Analysis: Public Issue Management in Turbulent Times, $4^{\text {th }}$ ed., Nelson Education, Toronto.

Pülzl H., Treib O. (2007), Implementing Public Policy [w:] F. Fischer, G.J. Miller, M.S. Sidney (eds.), Handbook of Public Policy Analysis: Theory, Politics and Methods, CRC Press, BocaRaton, London-New York.

Reno Ph. (2011), Politychne, polityka [w:] B.Kassen, K.Sigov (eds.) European Dictionary of Philosophy: Lexicon of Implications, Vol. 2, $2^{\text {nd }}$ ed., Duch i Litera, Kyiv.

Szarfenberg R. (2013), Nauki o i dla polityki publicznej: podejścia teoretyczno-metodologiczne [w:] A. Wojciuk (red.) Analiza polityki publicznej. Podejścia teoretyczno-metodologiczne, Instytut Badań Edukacyjnych, Warszawa.

Szarfenberg R. (2016), Polityka publiczna - zagadnienia i nurty teoretyczne, „Studia z Polityki Publicznej”, 1(9).

Teleshun S., Sitnik S., Reiterovich I. (2012), Publitychna chy derzavna polityka - vitchyzniana dilemma wyboru, „Bulletin of the National Academy of Public Administration under the President of Ukraine", 4.

Treib O. (2006), Implementing and Complying with EU Governance Outputs, „Living Reviews in European Governance", 1(1).

Treib O. (2014), Implementing and Complying with EU Governance Outputs, „Living Reviews in European Governance", 9(1).

Wallace C. (1993), Citizenship and Social Policy in East-Central Europe, Transformation Processes in Eastern Europe - Challenges for Socio-Economic Theory, 21, Academy of Economics, Cracow, Friedrich Ebert Foundation, Warsaw.

Warntjen A. (2016), Designing Democratic Institutions: Legitimacy and the Reform of the Council of the European Union in the Lisbon Treaty [w:] S. Dosenrode (ed.) The European Union after Lisbon: Polity, Politics, Policy, Routledge, London. 
Zagors'kyj V., Bunyk M. (2011), Publichna polityka [w:] Y. Kovbasyuk (ed.) Encyclopaedia of Public Administration, Vol. 8, L'viv Regional Institute of Public Administration under the President of Ukraine, L'viv.

Zybała A. (2015), Polityka publiczna wobec teorii i jej praktyki w Polsce, „Wrocławskie Studia Politologiczne", nr 18. 